\title{
O PLANEJAMENTO URBANÍSTICO E AMBIENTAL NA BACIA DO RIO CAMBORIÚ E CONTÍGUAS: A INTERDEPENDÊNCIA ENTRE DOIS MUNICÍPIOS
}

\section{Urbanistic and environmental planning in the Camboriu and Countiguous Watersheds: the interdependence between two Municipalities}

\author{
André Furlan Meirinho \\ Universidade do Estado de Santa Catarina - UDESC \\ Kelli Cristina Dacol \\ Universidade do Estado de Santa Catarina - UDESC \\ Valério Alécio Turnes \\ Universidade do Estado de Santa Catarina - UDESC
}

Informações do artigo

Recebido em 22/08/2020 Aceito em 02/09/2020

doi>: https://doi.org/10.25247/2447-861X.2020.n251.p690-715

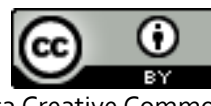

Esta obra está licenciada com uma Licença Creative Commons Atribuição 4.0 Internacional.

\section{Como ser citado (modelo ABNT)}

MEIRINHO, André Furlan; DACOL, Kelli Cristina; TURNES, Valério Alécio. O planejamento urbanístico e ambiental na Bacia do Rio Camboriú e Contíguas: a interdependência entre dois municípios. Cadernos do

CEAS: Revista Crítica de Humanidades.

Salvador/Recife, v. 45, n. 251, p. 690-715, set./dez. 2020. DOI: https://doi.org/10.25247/2447-861X.2020.n251.p6go-715

\begin{abstract}
Resumo
A pesquisa se propôs a analisar como tem sido realizado o planejamento urbanístico e ambiental no âmbito da Bacia Hidrográfica do Rio Camboriú e Contíguas, que inclui os municípios de Camboriú e de Balneário Camboriú. A metodologia adotada consistiu em pesquisa bibliográfica e análise documental baseada nos planos municipais relacionados à temática. Para apoio metodológico, foi elaborada uma matriz de avaliação contendo critérios, pontuações acerca do planejamento em ambos os municípios e um conceito final. $O$ resultado da avaliação identificou um planejamento urbanístico e ambiental insatisfatório, tecnicamente desarticulado, frágil quanto aos processos de participação e controle social e sem atendimento ao princípio da intersetorialidade. $\mathrm{O}$ que reflete na dificuldade dos municípios em alcançar solução para os problemas que thes são comuns. Chegou-se à conclusão de que ambos os municípios são interdependentes e necessitam de planejamentos intersetoriais e intermunicipais, pensados além da divisão territorial e político administrativa, que se considere a bacia hidrográfica para tratar dos recursos naturais e a escala regional envolvendo a região metropolitana para tratar de temas comuns como a mobilidade urbana.
\end{abstract}

Palavras-Chave: Planejamento urbano. Planos municipais. Bacia Hidrográfica. Rio Camboriú. Avaliação.

\section{Abstract}

The research set out to analyse how urban and environmental planning has been carried out within the Camboriú and Contiguous Watershed, which includes the municipalities of Camboriú and Balneário Camboriú. The adopted methodology consisted of bibliographic research and documentary analysis based on the municipal plans related to the theme. For methodological support, an evaluation matrix was developed containing criteria, scores on planning in both municipalities and a final concept. The result of the evaluation identified an unsatisfactory urban and environmental planning, technically disjointed, fragile in terms of the processes of participation and social control and without complying with the principle of intersectoriality. This reflects the difficulty of the municipalities in reaching a solution to the problems that are common to them. It was concluded that both municipalities are interdependent and need intersectoral and intermunicipal planning, designed beyond the territorial and political administrative division, which considers the watershed to deal with natural resources and the regional scale involving the metropolitan region to deal with common themes such as urban mobility.

Keywords: Urban planning. Municipal plans. Watershed. Camboriú River. Evaluation. 


\section{Introdução}

A complexidade dos problemas de caráter urbanístico e ambiental que emerge nos municípios, ultrapassa, muitas vezes, os limites político-administrativos, o que indica a interdependência entre os municípios e a necessidade de se considerar a bacia hidrográfica como unidade de base em alguns planejamentos públicos.

O crescente debate na agenda pública sobre sustentabilidade ambiental e desenvolvimento dos municípios leva ao entendimento de que é fundamental considerar a bacia hidrográfica como unidade de planejamento para as questões de ordem ambiental. Neste sentido, a presente pesquisa propõe analisar como tem sido realizado o planejamento urbanístico e ambiental nos territórios de Camboriú e de Balneário Camboriú, municípios que compõem a Bacia Hidrográfica do Rio Camboriú e Contíguas.

A pesquisa está pautada em princípios democráticos inerentes ao planejamento público, que foram abarcados na legislação brasileira após processo de redemocratização do país, bem como pelo conceito de planejamento e tipologias abordadas por Marcelo Lopes de Souza no livro "Mudar a Cidade".

Apesar de traçar aspectos futuros, o planejamento é indissociável da gestão. Não se pode planejar, sem pensar na gestão do objeto do planejado. Além disso, o planejamento urbano, especificamente, é interdisciplinar, pois depende de olhares dos mais diversos técnicos. Para acontecer, o planejamento e a gestão urbanos precisam aliar as dimensões técnica e científica com a política, sem deixar de considerar a liberdade dos indivíduos e a heterogênea massa da sociedade como um todo, haja vista que o exercício do seu poder de escolha também produz os espaços públicos (SOUZA, 2010).

Sendo a interdisciplinaridade um princípio do planejamento, logo, pode-se afirmar que o planejamento ambiental tem estreita relação com o planejamento urbanístico, pois não há como pensar o espaço urbano sem considerar os aspectos ambientais envolvidos nas mais diversas áreas, incluindo os princípios democráticos de participação social inerentes às legislações estabelecidas após a Constituição Federal de 1988. 
Por esta razão, a Política Nacional de Meio Ambiente e o Estatuto das Cidades são dois marcos legais que apontam os caminhos do trabalho. Também complementam as diretrizes da pesquisa outras legislações relacionadas à temática. ${ }^{1}$

Tendo como premissa a exigência de se estabelecer planos municipais conferida aos municípios pelas legislações citadas, a pesquisa utiliza para a análise documental o Plano de Recursos Hídricos da bacia, os planos diretores e demais planos municipais ou setoriais existentes. A partir destes instrumentos, da análise da legislação, da bibliografia de Marcelo Lopes de Souza e do levantamento documental, estabelece-se uma matriz de avaliação dos planos existentes nos dois municípios em análise, gerando um conceito final, a fim de contribuir para a responder às questões de investigação.

Neste sentido, tomando como pressuposto a fragilidade dos processos de planejamento público, especialmente acerca da elaboração dos planos municipais, bem como o panorama desigual dos municípios em análise, é que se justifica o mérito da investigação. Sob este entendimento, a pesquisa pretende responder às seguintes questões: os planos municipais relacionados aos aspectos urbanísticos e ambientais atendem ao escopo mínimo exigido? Como tem sido realizado o planejamento urbanístico e ambiental nos municípios de Camboriú e de Balneário Camboriú? Quais os reflexos do planejamento no âmbito da bacia?

\section{Caracterização da área de estudo}

A Bacia Hidrográfica do Rio Camboriú e Contíguas faz parte da Região Hidrográfica do Vale do Itajaí $\left(\mathrm{RH}_{7}\right)$, compreendendo $220,74 \mathrm{~km}^{2}$. O território situa-se no litoral centro norte catarinense e abrange predominantemente os municípios de Balneário Camboriú e

\footnotetext{
1 Lei Federal 11.124, de 16 de junho de 2005, que institui o Sistema Nacional de Habitação de Interesse Social SNHIS; Lei Federal n 9.433, de 08 de janeiro de 1997, que define a Política Nacional de Recursos Hídricos Lei Federal no 11.445, de 05 de janeiro de 2007, que estabelece diretrizes nacionais para o saneamento básico; Lei Federal 12.187, de og de dezembro de 2009 sobre a Política Nacional sobre Mudança do Clima - PNMC; Lei Federal 12.305, de 02 de agosto de 2010, que traz a Política Nacional de Resíduos Sólidos; Lei Federal 12.608, de 10 de abril de 2012, que institui a Política Nacional de Proteção e Defesa Civil - PNPDEC; Lei Federal 12.587, de 03 de janeiro de 2012 no que se refere à Política Nacional de Mobilidade Urbana. Disponível: http://www4.planalto.gov.br/legislacaol. Acesso em: 10 de dez. 2019.
} 
Camboriú, mais uma pequena porção de Itajaí ${ }^{2}$ (Ver Mapa 1). Hidrograficamente abrange a Bacia do Rio Camboriú, com 199,8 km², além do Rio Marambaia e de outros corpos hídricos situados na região da Interpraias e da Praia dos Amores. Tem como curso d'água principal, e único manancial da bacia, o rio Camboriú, que possui aproximadamente $40 \mathrm{~km}$ de extensão, nasce em Camboriú e deságua na praia central da cidade de Balneário Camboriú. Além do rio Camboriú, os principais afluentes o rio do Braço, Macacos, Pequeno, Lageado e Canoas. (CIRAM/EPAGRI, 2010; DACOL, 2013; SANTA CATARINA, 2018).

A caracterização do ambiente natural da região abrange diversas tipologias e composições vegetais, as quais são específicas das áreas costeiras do sul/sudeste do país, tais como Floresta Ombrófila Densa (Mata Atlântica), que ocupa áreas de encostas cristalinas e manguezais; restingas e banhados, que se formam sobre as planícies quaternárias, de formação sedimentar. Ecossistemas estes que foram e continuam tendo a qualidade ambiental (redução da biodiversidade da fauna e flora e contaminação de recursos hídricos) afetada pela ocupação antrópica decorrente do crescimento urbano turístico da região, consagrado pelas belezas naturais e incentivado pelo mercado imobiliário. (SKALLE e REIS, 2008).

Mapa 1 - Localização da Bacia Hidrográfica do Rio Camboriú e Contíguas

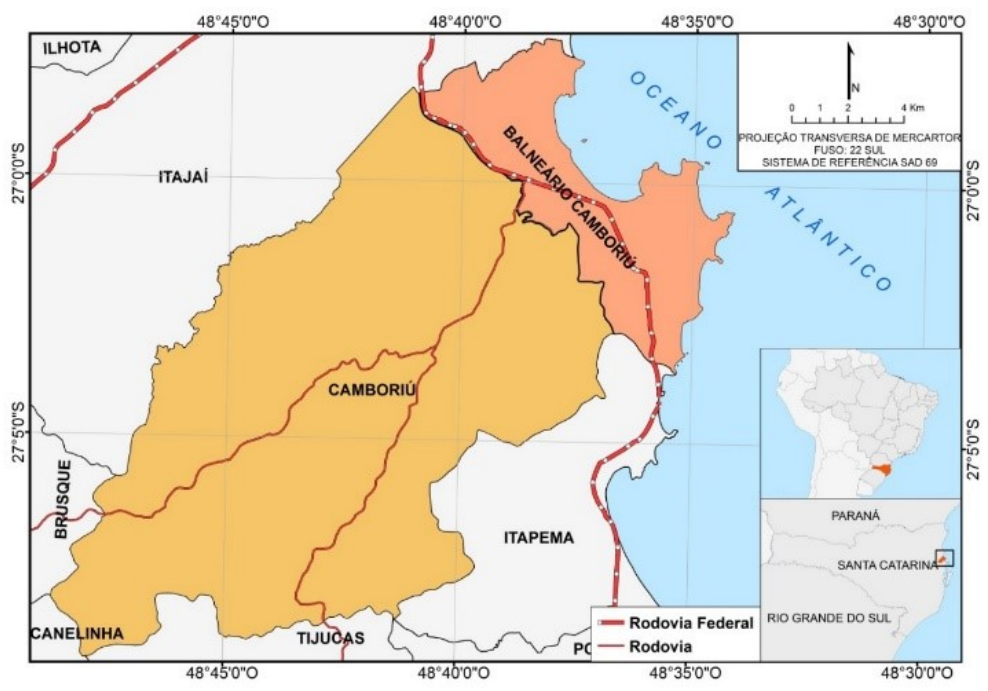

Fonte: CIRAM/EPAGRI, 2010.

2 A porção de Itajaí, devido seu tamanho e baixa influência, não é relevante para a análise desta pesquisa. 
Histórico de ocupação na Bacia

A história de ocupação nos municípios que fazem parte da bacia relata a presença de indígenas, consenso popular relata a capela em 1758, porém sem comprovação histórica. Em 1840, foi criada a Paróquia, em 1849 a Freguesia, data instituída como marco de fundação do território pela Lei Municipal de Balneário Camboriú nº 4259/2019. Inicialmente pertencente a Porto Belo, mais tarde a Itajaí, sendo emancipado em 1884 e instalado município em 1885. Houve mudança da sede da região da "Barra" para "Vila Garcia" (atualmente município de Camboriú) a partir de 189o. Na década de 1920, começou o povoamento teuto-brasileiro com as primeiras casas de veraneio no centro da praia de Camboriú (atualmente praia central de Balneário Camboriú). Os veranistas vinham do Vale do Itajaí, especialmente Blumenau. Foi a partir do povoamento pelos alemães que se inicia o progresso, infraestrutura e melhoramentos e as primeiras hotelarias. Com o fim da segunda-guerra mundial, a partir da década de 1960 o fluxo de turistas teuto-brasileiros aumentou e, em seguida, miscigenou-se com as mais diversas raças, línguas e nações. Até este momento - desde 1884 quando foi criado o município de Camboriú - havia apenas um município, Camboriú, sendo que o município de Balneário Camboriú foi criado somente no ano de 1964 (CORRÊA, 2019; SCHLIKMANN, 2016; BALNEÁRIO CAMBORIÚ, 2019).

O ano de 1964 é um registro relevante para esta pesquisa porque marca a divisão territorial e a separação jurídico-institucional dos municípios da bacia. A separação dos municípios traz ao presente artigo importantes reflexões acerca das atuais dificuldades de se considerar a bacia hidrográfica como unidade de planejamento ambiental. Em especial, as discrepâncias entre os municípios, no que concerne aos indicadores avaliados e aos problemas ambientais enfrentados devido à não consonância entre os seus planejamentos urbanístico-ambientais.

Uso e ocupação do solo na Bacia

Os principais usos produtivos da terra na bacia destinam-se ao cultivo do arroz irrigado e à pastagem. Há presença significativa de floresta nas cabeceiras localizadas na área rural do município de Camboriú.

Como pode-se verificar no mapa, Balneário Camboriú é totalmente urbanizada. As áreas urbanas de ambos os municípios, destacadas em rosa, são contíguas. O que indica a 
necessidade de planejar e pensar solução conjunta para alguns problemas comuns entre os municípios, como, por exemplo, a mobilidade urbana.

Destacam-se pontos de degradação ambiental decorrente do manejo inadequado dos plantios, solo exposto devido à monocultura de eucalipto e pinus, assim como em função da expansão de áreas cultivadas, de pastagens e carvoarias (URBAN, 2008).

Mapa 2 - Uso da terra na bacia

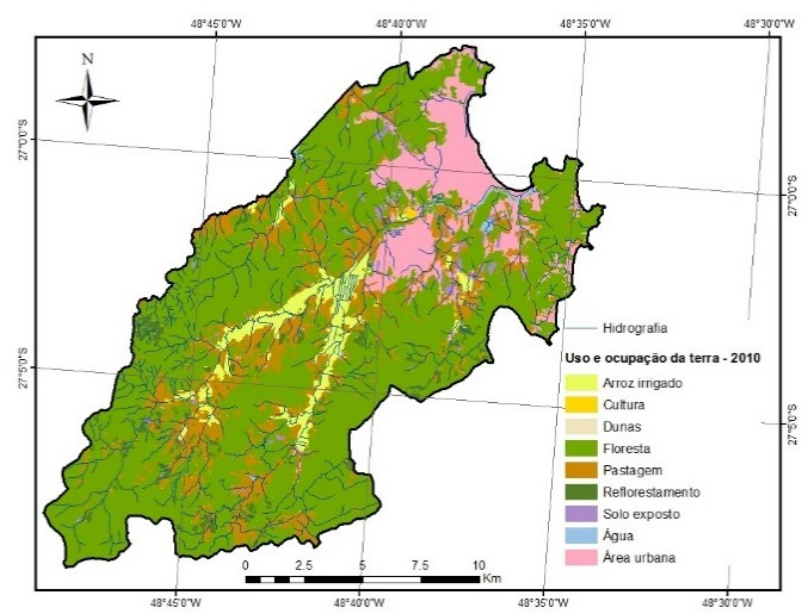

Fonte: CIRAM/EPAGRI, 2010.

Aspectos demográficos

Ambos os municípios da bacia somam 225.184 habitantes fixos, conforme estimativa do IBGE de 2018. O aumento populacional passou a ter crescimento significativo a partir da década de 1970. Uma das razões foi a implantação da Rodovia BR 101, que ocorreu nesse período. De 1980 a 1991, a população duplicou em Balneário Camboriú. 
Tabela 1 - Comparação da população rural, urbana e total nos municípios de Camboriú e Balneário Camboriú entre 1970 a 2010

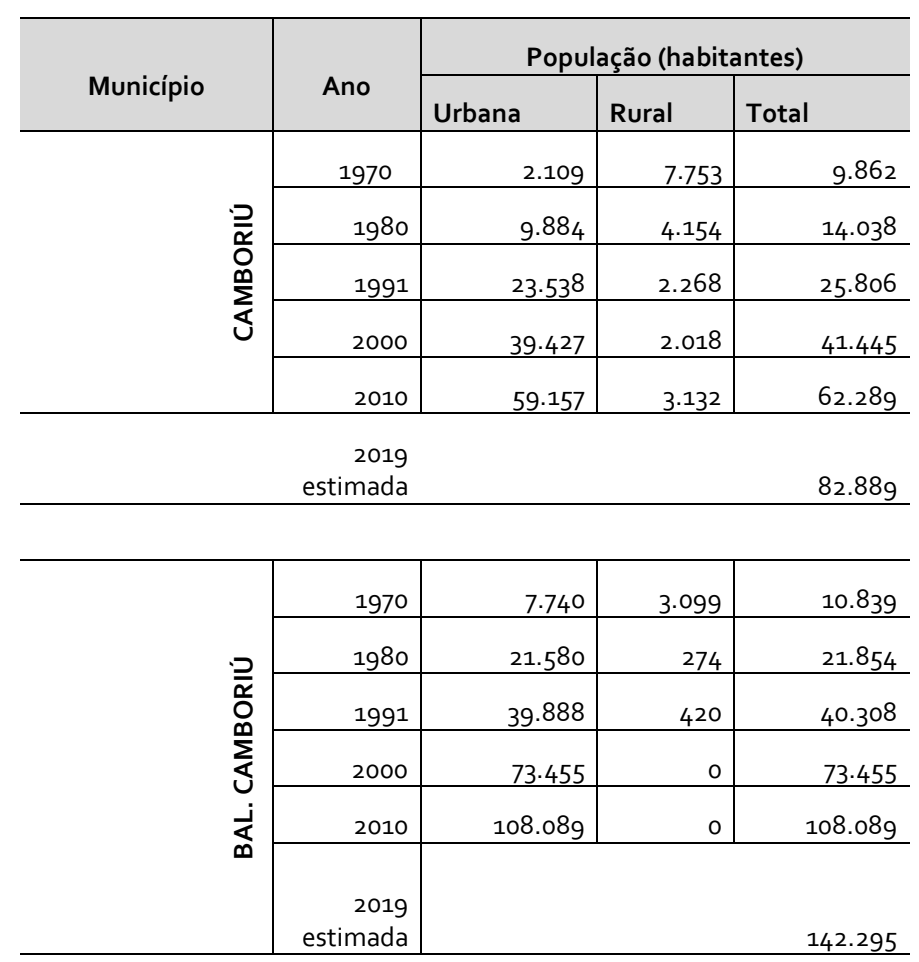

Fonte: Censos Demográficos de 1980 a 2010 (IBGE, 2019).

\section{Camboriú}

De acordo com os registros históricos de Corrêa (2019), o município foi criado através da Lei Estadual 1.076, de 5 de abril de 1884, antes disso, foi distrito e vila de Itajaí.

Conforme Censo realizado no ano de 2010, possui 62.361 habitantes e uma população estimada em 2019 de 82.889 pessoas. A densidade demográfica é de 293,68 habitantes por quilômetro quadrado. O Produto Interno Bruto per capta em é de R\$17.154,54 (dezessete mil, cento e cinquenta e quatro reais e cinquenta e quatro centavos). O Índice de Desenvolvimento Humano Municipal levantado no ano é de o,726. Quanto ao território, abrange a área de $211,709 \mathrm{~km}^{2}$ e ambientalmente pertence ao sistema costeiro marinho e faz parte do bioma Mata Atlântica. Possui 89,2\% de esgotamento sanitário3, esse percentual

\footnotetext{
3 A informação do IBGE não especifica o tipo de esgotamento sanitário. O índice corresponde ao sistema de
} fossa e filtro e não de sistema de coleta e tratamento de esgoto público. 
corresponde ao sistema de fossa e filtro, há $33,4 \%$ de arborização urbana e $31,7 \%$ de vias públicas urbanizadas4. (IBGE, 2019).

No município de Camboriú, a ocupação tem crescido, visto a presença de áreas livres. Ainda, há predominância de área rural, onde se localizam as nascentes dos principais rios da bacia. Apesar dos usos bastante heterogêneos, identifica-se, no Mapa 2, significativa área de arroz irrigado nas áreas baixas.

\section{Balneário Camboriú}

O município de Balneário de Camboriú foi criado por meio da Lei Estadual n. ${ }^{\circ}$ 960, de 08, de abril de 1964, sendo que a Lei Estadual n. ${ }^{\circ}$ 5.630, de 20, de novembro de 1979 alterou sua denominação para Balneário Camboriú, retirando-se o "de".

Possui 108.089 habitantes, conforme Censo realizado no ano de 2010 e uma população estimada em 2019 de 142.295 pessoas. A densidade demográfica é de 2.337,67 habitantes por quilômetro quadrado. O Produto Interno Bruto per capta é de $\mathrm{R} \$ 38.061,55$ (trinta e oito mil, sessenta e um reais e cinquenta e cinco centavos). O Índice de Desenvolvimento Humano Municipal é de 0,845. Quanto ao território, abrange a área de $47,214 \mathrm{~km}^{2}$ e ambientalmente pertence ao sistema costeiro marinho e faz parte do bioma Mata Atlântica. Possui 98,7\% de esgotamento sanitário 5 de cobertura domiciliar por sistema de coleta e tratamento a de esgoto, $71 \%$ de arborização urbana e $89,6 \%$ de vias públicas urbanizadas $^{6}$ (IBGE, 2019).

O município de Balneário Camboriú é totalmente urbano, pois, desde a Lei Municipal n 1.677, de 11 de julho de 1997 deixou de possuir área rural.

O uso e ocupação do solo são disciplinados pela Lei no 2.794 de 14 de janeiro de 2008, através da qual se apresenta a divisão territorial em nove macrozonas de ambientes construídos (MAC), mais três macrozonas de ambientes naturais (MAN). O microzoneamento é subdividido em 41 zonas, conforme área de maior ou menor adensamento, restrição, especificidades especiais e vocação, sendo predominante a zona de ambientes construídos consolidados de alta densidade. (DACOL, 2013)

\footnotetext{
4 Possui bueiro, calçada, pavimentação e meio-fio.

5 Trata-se de sistema de coleta e tratamento de esgoto por aeração prolongada.

6 Possui bueiro, calçada, pavimentação e meio-fio.
} 
O município de Balneário Camboriú tem a totalidade da área urbana. Sendo densamente ocupado ao longo da sua faixa litorânea. Atualmente, ainda há presença de áreas verdes nas extremidades da área mais adensada, as quais se tratam de áreas de proteção, cuja ocupação é restrita. Uma das áreas refere-se à região das Praias Agrestes onde se localiza a Área de Proteção Ambiental - APA Costa Brava7.

A população fixa sofre significativa alteração devido à sazonalidade. Na temporada de verão, a cidade chega a receber um incremento de turistas, chegando a triplicar a quantidade de pessoas na cidade. (SANTA CATARINA, 2015).

\section{Metodologia}

O universo da pesquisa abrange a Bacia Hidrográfica do Rio Camboriú e Contíguas e o recorte para análise corresponde aos municípios de Camboriú e Balneário Camboriú.

A metodologia adotada consistiu no levantamento da legislação relacionada, pesquisa bibliográfica e análise documental. Também considerou dados secundários como, por exemplo, dados demográficos e indicadores municipais.

A análise do planejamento urbanístico e ambiental na bacia incluiu o Plano de Recursos Hídricos da Bacia Hidrográfica do Rio Camboriú, de escala regional, bem como os planos municipais/setoriais, relacionados à temática da pesquisa, desenvolvidos nos municípios de Camboriú e Balneário Camboriú, bem como documentos relativos às políticas públicas da área de pesquisa.

Com base nos princípios e diretrizes da Política Nacional de Meio Ambiente, do Estatuto da Cidade e de outras políticas ambientais relacionadas, foi elaborada uma Matriz de Avaliação das políticas e dos planos municipais analisados. A elaboração da matriz utilizou como referência o formato de um roteiro de avaliação de planos municipais de saneamento editado pelo extinto Ministério das Cidades, porém, todo o conteúdo da matriz foi elaborado pelos autores, com base em critérios, conceito de cada critério, subcritérios, orientação,

7 O Plano de Manejo da APA Costa Brava e o potencial construtivo estão sendo elaborados e discutidos pela segunda vez. A composição do primeiro conselho foi questionada judicialmente. A participação da sociedade é limitada devido ao direcionamento dos debates por um grupo de participantes de opinião homogênea, interessados no aumento do gabarito de construção e em liberar a ocupação das morrarias e promontórios. 
células de pontuação, justificativa/ observação, somatório das pontuações, média aritmética e resultado final.

O preenchimento da matriz foi norteado por oito critérios: compatibilidade; intersetorialidade; integralidade; participação social; dimensão temporal; dimensão demográfica; presença de instrumentos de planejamento; e mecanismos de monitoramento e avaliação. Para avaliação de cada critério, também foram considerados subcritérios e atribuída uma pontuação de "o" a " 5 " para item analisado.

Como resultado, obteve-se a soma total da pontuação de cada município e sua respectiva média aritmética. Com base na somatória dos dois municípios, obteve-se uma média final que correspondeu a um dos conceitos "muito insatisfatório", "insatisfatório", "satisfatório" ou "muito satisfatório" conferido ao planejamento urbanístico e ambiental no âmbito da bacia.

Além da avaliação dos planos e das políticas por meio da matriz, foi identificada a existência de fundos e órgãos colegiados na forma de conselhos, correspondentes aos planos analisados em cada município. Os quais foram apresentados na forma de tabela e gráficos.

Também foram levantados os principais problemas urbanísticos e ambientais na bacia, a fim de complementar a análise.

\section{Análise e discussão}

Neste item será contextualizado, brevemente, o histórico de planejamento público, no intuito de demonstrar em que momento o planejamento começou a ser mais instrumentalizado nos municípios, através dos planos municipais. São abordadas algumas tipologias de planejamento para nortear a pesquisa, e, de forma mais aprofundada, realizada a análise do planejamento urbanístico e ambiental na bacia do Rio Camboriú e Contíguas.

Planejamento público: dos planos nacionais aos planos municipais

Não há pretensão de se aprofundar na história do planejamento público brasileiro, tema compreendido em inúmeros estudos da literatura. Cabe, aqui, tão somente pinçar alguns marcos da trajetória do planejamento brasileiro, entre as décadas de 1930 e 1980, e os desdobramentos após Constituição Federal de 1988. 
O intuito é discorrer sobre a desconcentração do planejamento governamental, especialmente a mudança de perspectiva a partir da Constituição Federal de 1988, que evoluiu, ainda que a passos lentos, para uma maior participação dos municípios e inserção da sociedade nos processos de planejamento urbanístico e ambiental.

O primeiro plano quinquenal brasileiro, denominado Plano Especial de Obras Públicas e Reaparelhamento da Defesa Nacional (1939-1943), que, após revisto, passou a ser denominado Plano de Obras e Equipamentos (POE), consistia no rearranjo de orçamento, alocação de verbas e controle de projetos (Ver Quadro 1). Os planos nacionais dos anos subsequentes (1950; 1956; 1962; 1964-66; 1968-70; 1972-74; 1975-79; 1980-85; 1986-89) apesar de, por vezes, apresentarem-se sobre bases ideológicas ou cenários políticos diferentes, todos estiverem, de algum modo, voltados ao crescimento econômico (movido pela industrialização), à infraestrutura, aos investimentos das indústrias de base, em tentativas frustradas de equilibrar as dimensões econômica e social, ou, ainda, voltados ao combate da inflação. (IPEA, 2010).

Embora se destaque, neste período, a existência de planejamento por parte governo, os planos estavam centralizados na Administração Pública Federal. Além disto, uma frase célebre, dita pelo ex-ministro da Fazenda na década de 1960, Antônio Delfim Neto, representa o cenário desse período: "primeiro temos de fazer o bolo crescer para depois distribuí-lo" ${ }^{18}$. Ou seja, a primazia do planejamento focava no crescimento a qualquer custo, em detrimento das políticas de redução das desigualdades.

Souza (2010) relembra o ano de 1973, quando houve o primeiro choque do petróleo e aumento da crise do sistema capitalista e que abalou as bases do planejamento até então orientado por influências dos países do Reino Unido, França e Alemanha. Na passagem das décadas de 1970 para 1980, o neoliberalismo passou a ser representado pela nova direita da Inglaterra e dos Estados Unidos. Sendo que, em 1980, devido ao enfraquecimento do pensamento da esquerda, há uma queda do keynesianismo, da social democracia e do dito Estado do Bem-Estar Social (Welfare State). Com isso, o planejamento brasileiro perdeu (e

8 Disponível em:https://www.gazetadopovo.com.br/opiniao/artigos/fazer-o-bolo-crescer-para-depois-dividilol. Acesso em: 11 de dez. 2019. 
vem perdendo) espaço diante do imediatismo e do privatismo decorrentes do Estado pósdesenvolvimentista.

Assim também, os anos seguintes destacam-se pelo imediatismo da gestão focada apenas nos planos de estabilização econômica, que perduraram alguns anos na busca de maior controle inflacionário.

A insatisfação política, a crise econômica e o descrédito institucional dão início ao processo de redemocratização brasileira e também novas formas de pensar o planejamento começam a ser debatidas.

A Constituição Federal de 1988, além de simbolizar a máxima do que constitui um Estado Democrático de Direito ditando regramentos aos direitos individuais, coletivos, ambientais e sociais, traz, em seu Art. 18, que "a organização política-administrativa da República Federativa do Brasil compreende a União, os Estados e os Municípios, todos autônomos, nos termos desta Constituição". No $\$ 3^{\circ}$ do Art. 25 define algumas prerrogativas dos Estados: "instituir regiões metropolitanas9, aglomerações urbanas e microrregiões, constituídas por agrupamentos de municípios limítrofes, para integrar a organização, o planejamento e a execução de funções públicas de interesse comum". E, no seu Art. 30, define como competências municipais

I - legislar sobre assuntos de interesse local;

II - suplementar a legislação federal e a estadual no que couber;

III - instituir e arrecadar os tributos de sua competência, bem como aplicar suas rendas, sem prejuízo da obrigatoriedade de prestar contas e publicar balancetes nos prazos fixados em lei;

IV - criar, organizar e suprimir distritos, observada a legislação estadual;

$\mathrm{V}$ - organizar e prestar, diretamente ou sob regime de concessão ou permissão, os serviços públicos de interesse local, incluído o de transporte coletivo, que tem caráter essencial;

VI - manter, com a cooperação técnica e financeira da União e do Estado, programas de educação infantil e de ensino fundamental;

VII - prestar, com a cooperação técnica e financeira da União e do Estado, serviços de atendimento à saúde da população;

9 Os municípios de Camboriú e Balneário Camboriú fazem parte da Região Metropolitana da Foz do Rio Itajaí e em conjunto com Itajaí, Navegantes e Penha constituem seu núcleo metropolitano. Além disto, a região é composta por uma área de expansão integrada pelos municípios de Bombinhas, Itapema, Balneário Piçarras e Porto Belo, necessitando, ainda, de ações para efetivar as políticas públicas de integração e desenvolvimento sustentável do território, conforme Lei Complementar Estadual n 495, de 26 de janeiro de 2010. Disponível em: http://leisestaduais.com.br/sc/lei-complementar-n-495-2010-santa-catarina-institui-asregioes-metropolitanas-de-florianopolis-do-vale-do-itajai-do-norte-nordeste-catarinense-de-lages-da-fozdo-rio-itajai-carbonifera-e-de-tubarao. Acesso em: 10 de dez. 2019. 
VIII - promover, no que couber, adequado ordenamento territorial, mediante planejamento e controle do uso, do parcelamento e da ocupação do solo urbano;

IX - promover a proteção do patrimônio histórico-cultural local, observada a legislação e a ação fiscalizadora federal e estadual.

Após a Constituição Federal de 1988 é que o planejamento público municipal se torna uma obrigatoriedade, visto que se instituiu o modelo federativo, dando certa autonomia aos municípios e novas diretrizes para o planejamento e os orçamentos públicos. A CF/88 também trouxe possibilidades de planejar a partir da organização de diferentes escalas regionais.

A nova tentativa de se retomar o planejamento, tendo como pano de fundo o Estado Democrático de Direito, se ampara em alguns pontos

a participação da sociedade na definição das prioridades nacionais, o estabelecimento de um novo modelo de relações federativas adaptado à autonomia dos governos subnacionais, a regulamentação dos novos dispositivos constitucionais que tratam de matérias correlatas e a preocupação com a eficiência e a eficácia da gestão pública. Ademais, chamava atenção para um ponto de fundamental importância: uma convivência harmônica entre os Poderes da República como condição indispensável para a coordenação das decisões de políticas públicas, da qual, como vimos, depende a eficácia do planejamento. (IPEA, p. 187, 2010)

Os direitos individuais, coletivos, sociais e ambientais previstos na CF/88, dependeriam de regulamentação através de legislações específicas, estas que trariam a obrigatoriedade dos planos municipais. Um exemplo, no caso de legislações urbanísticas, que interessa ao propósito desta pesquisa, é a Lei Federal 10.520 de 2001, que trata do Estatuto da Cidade e trouxe a obrigatoriedade, a municípios acima de 20 mil habitantes, da elaboração dos Planos Diretores Municipais. Outros exemplos são algumas legislações de caráter ambiental, quais sejam: Lei Federal n 9.433/1997, que trata da Política Nacional de Recursos Hídricos e obriga a União e o Estado, por meio dos órgãos descentralizados de participação social - os Comitês de Bacia - a elaborarem o Plano de Recursos Hídricos da bacia hidrográfica, conforme dominialidade à qual condiz seu rio principal; a Lei Federal no 11.445/2007, que dispõe sobre a Política Nacional de Saneamento Básico e define a obrigatoriedade dos Planos Regionais ou Municipais de Saneamento Básico; a Lei Federal no 
12.305/2010, que define a Política Nacional de Resíduos Sólidos e, igualmente, exige o Plano Regional ou Municipal de Gerenciamento Integrado de Resíduos Sólidos, entre outras.

O que se pode verificar é que a necessidade dos Planos Municipais surgiu após as legislações regulamentadoras da CF/88. Isso representa um avanço para se pensar a ocupação do espaço urbano e os problemas ambientais da cidade. Entretanto, é necessário que haja planejamento orientado de forma multidisciplinar, com transparência no uso dos recursos públicos e com processo continuado de ampla participação social, desde a elaboração, a implementação até a avaliação dos planos. Para isto, há que se institucionalizar dois elementos complementares ao plano, o fundo e o conselho, esta tríade, em qualquer que seja a área, é que irá dar base para a execução das políticas públicas.

Tipologias de planejamento

Recorrendo aos estudos de geografia e da sociologia urbana, traz-se aqui uma síntese do amontoado de correntes ideológicas, políticas e econômicas nacionais e internacionais que se alternaram e foram determinantes para a evolução do conceito de planejamento. A priori, utilizou-se as tipologias de planejamento apresentadas no Quadro 1, pelo fato de demonstrarem o contexto em que se situam os primeiros planos nacionais elaborados pelo governo, mas que também servem para identificar o possível enquadramento dos planos municipais elaborados no âmbito da bacia do Rio Camboriú.

Souza (2010) sistematizou algumas tipologias de planejamento (Ver Quadro 1). Esta sistematização baseou-se em oito critérios (ideia-força central; filiação estética; escopo; grau de interdisciplinaridade; permeabilidade em face da realidade; grau de abertura com a participação popular; atitude em face do mercado referencial político filosófico), sob os quais ele subsidia sua análise da oposição entre o planejamento convencional e o não convencional. Por fim, ao tecer críticas, seja às bases conceituais, às teorias ou à aplicação metodológica propriamente dita, Ele compartilha a perspectiva autonomista e auto gestionária, a partir da reflexão político filosófica de Castoriadis. 
Quadro 1-Tipologias de Planejamento

\begin{tabular}{|c|c|c|}
\hline Tipologia & Dimensão & Influência \\
\hline $\begin{array}{l}\text { Planejamento } \\
\text { físico-territorial } \\
\text { convencional } \\
\text { (blueprint } \\
\text { planning) }\end{array}$ & $\begin{array}{l}\text { Planejamento mais antigo, denominado também como clássico, baseado } \\
\text { na força regulatória do Estado e no ordenamento espacial. Tem como } \\
\text { pressuposto a cidade ideal. Já havia base intelectual antes dos anos } 40, \\
\text { inclusive em estudos urbanísticos de Le Corbusier, tendo sido incorporado } \\
\text { nacionalmente após a guerra de } 1939-45 \text { e com auge marcado entre os } \\
\text { anos } 50 \text { e } 60 \text {. }\end{array}$ & $\begin{array}{l}\text { Países do Reino Unido, } \\
\text { França e Alemanha }\end{array}$ \\
\hline $\begin{array}{l}\text { Planejamento } \\
\text { sistêmico } \\
\text { (systems } \\
\text { planning), }\end{array}$ & $\begin{array}{l}\text { Também obedece a uma abordagem clássica regulatória, porém com as } \\
\text { premissas epistemológicas, metodológicas, marcado pela cientificização } \\
\text { do planejamento, por maior racionalidade instrumental e tecnicidade. } \\
\text { Com foco no conjunto de múltiplos sistemas, enfoque abrangente e na } \\
\text { incorporação de dados científicos, desenvolveu-se entre as décadas de } \\
1960 \text { e } 1970 \text {. }\end{array}$ & $\begin{array}{l}\text { Espírito geddesiano. } \\
\text { Originado na Grã- } \\
\text { Bretanha. Teoria Geral } \\
\text { dos Sistemas }\end{array}$ \\
\hline $\begin{array}{l}\text { Planejamento } \\
\text { mercadófilo }\end{array}$ & $\begin{array}{l}\text { Teve início nos anos 80, com auge nos anos 9o, tinha como fio condutor o } \\
\text { espírito econômico em detrimento do regulatório, privilegiando o capital } \\
\text { imobiliário e os grupos dominantes sem dar espaço à voz popular. Marcado } \\
\text { também pela arquitetura pós-modernista (que incorpora, além do físico- } \\
\text { territorial, outras dimensões voltadas aos objetivos econômicos). Uma das } \\
\text { suas subdivisões apresenta-se como new urbanismo, que se opõe ao } \\
\text { planejamento naturalista (baixa densidade), definido por áreas de } \\
\text { concentração como estratégia de direcionamento de mercado. Apesar dos } \\
\text { títulos de modernidade, considera-se como modelo conservador. }\end{array}$ & $\begin{array}{l}\text { Espírito } \\
\text { empresarialismo e } \\
\text { neoliberalismo } \\
\text { originado nos EUA e } \\
\text { Inglaterra na década de } \\
1980\end{array}$ \\
\hline $\begin{array}{l}\text { Planejamento } \\
\text { ecológico }\end{array}$ & $\begin{array}{l}\text { Surge com o objetivo de considerar a preocupação com o meio ambiente } \\
\text { e com o desenvolvimento sustentável. Traz o foco para a modernização } \\
\text { com a sustentabilidade ecológica das cidades, visando ao equilíbrio entre } \\
\text { o desenvolvimento econômico e o viés ambiental. }\end{array}$ & $\begin{array}{l}\text { Relatório Brundtland de } \\
\text { 1988, que cunhou o } \\
\text { termo } \\
\text { Desenvolvimento } \\
\text { Sustentável }\end{array}$ \\
\hline $\begin{array}{l}\text { Planejamento } \\
\text { comunicativo/ } \\
\text { colaborativo }\end{array}$ & $\begin{array}{l}\text { Considera a ação comunicativa como meio para definir normas e valores } \\
\text { que tenham validade no processo e no contexto de planejamento. Tem } \\
\text { como pressuposto que a racionalidade comunicativa, fundamentada no } \\
\text { Estado Democrático do Direito e na soberania popular, é um meio capaz } \\
\text { de alcançar o consenso. Apesar de trazer uma abordagem não } \\
\text { conservadora, ao passo que considera a voz popular, não é considerado } \\
\text { suficiente porque não tem capacidade de consolidar a prática do agir } \\
\text { comunicativo devido às desigualdades e por não superar as contradições } \\
\text { de classes durante a construção do consenso a partir da persuasão. }\end{array}$ & $\begin{array}{l}\text { Teóricos de } \\
\text { planejamento urbano } \\
\text { anglo-saxões com } \\
\text { inspiração filosófica na } \\
\text { Teoria da Razão e do } \\
\text { Agir comunicativo de } \\
\text { Juergen Habermas }\end{array}$ \\
\hline $\begin{array}{l}\text { Planejamento } \\
\text { Rawlsiano }\end{array}$ & $\begin{array}{l}\text { Considera a teoria de Jhon Rawls, visando à ética da justiça enquanto } \\
\text { equidade. Baseia-se na crítica ao princípio de utilidade, que admite } \\
\text { compensação pelas perdas de alguns por meio dos ganhos de outros; } \\
\text { considera o princípio da diferença, mas não se aprofunda na heteronomia } \\
\text { estrutural como as divisões de classe de uma sociedade capitalista. } \\
\text { Representa uma evolução ideológica no pensar o planejamento, mas } \\
\text { considera a autonomia como liberdade pessoal, o que confere um caráter } \\
\text { individualista sem conseguir avançar para a interrelação do desigual com a } \\
\text { coletividade. }\end{array}$ & $\begin{array}{l}\text { Defendida por Shean } \\
\text { McConnel, com } \\
\text { reflexão filosófica de } \\
\text { Jhon Rawls, } \\
\text { especificamente na sua } \\
\text { concepção de "justiça } \\
\text { enquanto fairness" }\end{array}$ \\
\hline $\begin{array}{l}\text { Planejamento } \\
\text { baseado na } \\
\text { perspectiva } \\
\text { autonomista }\end{array}$ & $\begin{array}{l}\text { O planejamento possibilita a participação ativa da sociedade na melhor } \\
\text { acepção democrática, dando-lhes condições de planejar as políticas } \\
\text { públicas em todas as etapas, decidindo os caminhos e gerando a condição } \\
\text { de construir o consenso através do exercício da crítica e da autonomia } \\
\text { individual e coletiva. }\end{array}$ & $\begin{array}{l}\text { Relação entre } \\
\text { autonomia individual e } \\
\text { coletiva, defendida por } \\
\text { Castoriadis. Inclui o } \\
\text { caráter político no } \\
\text { planejamento. }\end{array}$ \\
\hline
\end{tabular}

Fonte: adaptado de Souza, 2010. 
Análise do planejamento urbanístico e ambiental na Bacia

A análise do planejamento urbanístico e ambiental na bacia do Rio Camboriú foi baseada nos planos municipais ${ }^{10}$ de Camboriú e Balneário Camboriú, considerando princípios e diretrizes da Política Nacional de Meio Ambiente, do Estatuto da Cidade, de outras políticas ambientais relacionadas. Também fazem parte da pesquisa dados de uso e ocupação do solo, aspectos demográficos e os problemas urbanísticos e ambientais comuns aos dois municípios em análise.

Foi considerado o total de 9 planos municipais relativos às legislações urbanísticas e ambientais, para averiguar a existência destes planos em cada município da bacia, a data de elaboração dos mesmos, bem como os respectivos conselhos como órgãos colegiados de participação social e fundos instituídos, conforme Tabela 2.

Tabela 2 - Relação de planos, conselhos e fundos existentes em cada município.

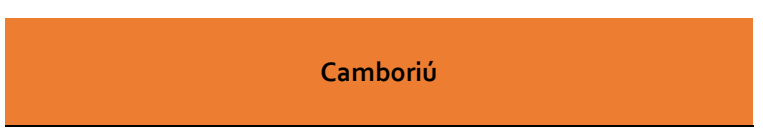

\begin{tabular}{lllll}
\multicolumn{1}{c}{ PLANOS MUNICIPAIS } & SI & ANO & C** & F*** \\
& N* & & & \\
\hline Plano de Meio Ambiente & $\mathrm{S}$ & 2013 & $\mathrm{~S}$ & $\mathrm{~S}$ \\
\hline Plano Diretor & $\mathrm{S}$ & 2017 & $\mathrm{~S}$ & $\mathrm{~S}$ \\
\hline Plano de Saneamento Básico & $\mathrm{S}$ & 2015 & $\mathrm{~S}$ & $\mathrm{~S}$ \\
\hline Plano de Resíduos Sólidos & $\mathrm{S}$ & 2018 & $\mathrm{~N}$ & $\mathrm{~S}$ \\
\hline Plano de Mudanças Climáticas & $\mathrm{N}$ & & $\mathrm{N}$ & $\mathrm{N}$ \\
\hline Plano de Defesa Civil & $\mathrm{N}$ & & $\mathrm{N}$ & $\mathrm{N}$ \\
\hline Plano de Mobilidade Urbana & $\mathrm{S}$ & 2017 & $\mathrm{~N}$ & $\mathrm{~N}$ \\
\hline Plano de Habitação de Interesse & $\mathrm{N}$ & & $\mathrm{N}$ & $\mathrm{N}$ \\
\hline Social & $\mathrm{N}$ & & $\mathrm{N}$ & $\mathrm{N}$ \\
\hline Plano de Drenagem Pluvial & & & &
\end{tabular}

\section{Balneário Camboriú}

\begin{tabular}{lllll}
\hline Plano de Meio Ambiente & N & & S & S \\
\hline Plano Diretor de Uso/ Ocupação do Solo & S & 2006 & S & S \\
\hline Plano de Saneamento Básico & S & 2013 & S & S \\
\hline Plano de Resíduos Sólidos & S & 2013 & S & S \\
\hline Plano de Mudanças Climáticas & N & & & \\
\hline Plano de Defesa Civil & $\mathrm{N}$ & & & \\
\hline Plano de Mobilidade Urbana & S & 2019 & $\mathrm{~S}$ & $\mathrm{~N}$ \\
\hline Plano de Habitação de Interesse Social & $\mathrm{S}$ & 2012 & $\mathrm{~S}$ & $\mathrm{~S}$ \\
\hline Plano de Drenagem Pluvial & $\mathrm{N}$ & & $\mathrm{N}$ & $\mathrm{N}$ \\
\hline
\end{tabular}

Do total de planos considerados relevantes para representar o planejamento urbanístico e ambiental, foram avaliados cinco planos existentes em cada município. A

\footnotetext{
${ }^{10}$ Os planos foram consultados nas versões digitais e impressas, sendo que parte da análise das informações de planejamento dos municípios foi possível devido à participação direta dos autores na gestão e conselhos municipais.
} 
análise foi baseada numa Matriz de Avaliação elaborada com oito critérios e subcritérios selecionados com base nos princípios e instrumentos presentes nas legislações analisadas, bem como pontuações e conceito final conforme itens identificados ou não identificados em cada município, Ver Tabela 3.

O município de Camboriú, apesar de estar em acentuado crescimento populacional nas últimas décadas, ainda possui área rural com extensas áreas de terra e recursos naturais a serem protegidos para garantir a qualidade ambiental na bacia. Porém, muitas áreas disponíveis estão ameaçadas de ocupação devido ao deslocamento do mercado da construção civil e mercado imobiliário que encontrou limites em Balneário Camboriú e visa manter sua sustentação.

Por outro lado, embora Balneário Camboriú possua situação econômica favorável, já adensou maior parte do seu território. Somado a isto, é uma cidade turística, que recebe uma população sazonal significativa, demandando maior infraestrutura, mais água e condições adequadas de mobilidade.

Tabela 3 - Matriz de avaliação do planejamento urbanístico e Ambiental no âmbito da Bacia do Rio Camboriú e Contíguas

\begin{tabular}{|c|}
\hline MATRIZ DE AVALIAÇÃO DO PLANEJAMENTO URBANÍSTICO E AMBIENTAL NO ÂMBITO DA BACIA \\
HIDROGRÁFICA DO RIO CAMBORIÚ \\
\hline TABELA DE CONTEÚDO E AVALIAÇÃO
\end{tabular}

Cada item da Tabela possui pontuação de "o, 1, 2, 3, 4, 5, sendo o (zero) "não identificado"; 1 (um) "muito ruim"; 2 (dois) "ruim"; 3 (três) "bom"; 4 (quatro) "muito bom"; 5 (cinco) "ótimo".

2. O resultado final da avaliação corresponde à média aritmética simples da soma total de cada município, que por sua vez será classificada da seguinte maneira: média menor ou igual a 1, resulta em MUITO INSATISFATÓRIO; média menor ou igual a 2 e maior que 1, resulta em INSATISFATÓRIO; média menor ou igual a 3 e maior que 2, resulta em SATISFATÓRIO; e média menor ou igual a 5 e maior que 3, resulta em MUITO SATISFATÓRIO.

\begin{tabular}{|c|c|c|c|c|c|c|}
\hline Item & Critério & $\begin{array}{l}\text { Conceito do } \\
\text { critério }\end{array}$ & Orientações & Município & Pont. & Justificativa / Observação \\
\hline \multirow{2}{*}{1} & \multirow{2}{*}{ COMPATIBILIDADE } & \multirow{2}{*}{$\begin{array}{l}\text { Considera a } \\
\text { compatibilidade } \\
\text { dos planos } \\
\text { municipais com a } \\
\text { Política e o Plano } \\
\text { de Recursos } \\
\text { Hídricos; }\end{array}$} & \multirow{2}{*}{$\begin{array}{l}\text { a) Os planos municipais são } \\
\text { compatíveis com o Plano de } \\
\text { Recursos Hídricos }=3 \\
\text { b) Os planos municipais } \\
\text { consideram apenas dados de } \\
\text { recursos hídricos relativos à } \\
\text { bacia hidrográfica para o } \\
\text { Diagnóstico e Prognóstico = } \\
2 \\
\text { c) Os planos municipais } \\
\text { consideram apenas dados de } \\
\text { recursos hídricos relativos à } \\
\text { bacia hidrográfica apenas } \\
\text { para o Diagnóstico }=1 \\
\text { d) Não identificado }=0\end{array}$} & Camboriú & 1 & $\begin{array}{l}\text { Os planos analisados foram } \\
\text { elaborados antes do Plano } \\
\text { Municipal de Recursos } \\
\text { Hídricos da Bacia } \\
\text { Hidrográfica do Rio } \\
\text { Camboriú e Contíguas } 2018 . \\
\text { Há necessidade de revisão e } \\
\text { compatibilização dos } \\
\text { mesmos. }\end{array}$ \\
\hline & & & & $\begin{array}{l}\text { Balneário } \\
\text { Camboriú }\end{array}$ & 1 & $\begin{array}{l}\text { Os planos analisados foram } \\
\text { elaborados antes do Plano } \\
\text { Municipal de Recursos } \\
\text { Hídricos da Bacia } \\
\text { Hidrográfica do Rio } \\
\text { Camboriú e Contíguas } 2018 \text {. } \\
\text { Há necessidade de revisão e } \\
\text { compatibilização dos } \\
\text { mesmos. }\end{array}$ \\
\hline
\end{tabular}




\begin{tabular}{|c|c|c|c|c|c|c|}
\hline \multirow[b]{2}{*}{2} & \multirow[b]{2}{*}{ INTERSETORIALIDADE } & \multirow[b]{2}{*}{$\begin{array}{l}\text { Considera a } \\
\text { intersetorialidade } \\
\text { interna (entre } \\
\text { setores/planos } \\
\text { relacionados no } \\
\text { âmbito do } \\
\text { município) e a } \\
\text { intersetorialidade } \\
\text { externa } \\
\text { (considera a } \\
\text { inter-relação dos } \\
\text { planos/setores } \\
\text { entre os } \\
\text { municípios no } \\
\text { âmbito da bacia) }\end{array}$} & \multirow[b]{2}{*}{$\begin{array}{l}\text { a) A intersetorialidade dos } \\
\text { planos municipais se dá } \\
\text { interna e externamente de } \\
\text { forma satisfatória }=3 \\
\text { b) A intersetorialidade dos } \\
\text { planos municipais se dá } \\
\text { apenas internamente ou } \\
\text { externamente }=2 \\
\text { c) A intersetorialidade se dá } \\
\text { apenas por dados ou } \\
\text { projetos específicos = } 1 \\
\text { d) Não identificado = o }\end{array}$} & Camboriú & 1 & $\begin{array}{l}\text { A inter-relação dos planos } \\
\text { municipais não foi } \\
\text { identificada entre os planos } \\
\text { do município menos ainda } \\
\text { entre os planos municipais do } \\
\text { outro município que } \\
\text { compartilha a bacia. }\end{array}$ \\
\hline & & & & $\begin{array}{l}\text { Balneário } \\
\text { Camboriú }\end{array}$ & 1 & $\begin{array}{l}\text { A inter-relação dos planos } \\
\text { municipais não foi } \\
\text { identificada entre os planos } \\
\text { do município menos ainda } \\
\text { entre os planos municipais do } \\
\text { outro município que } \\
\text { compartilha a bacia. Há } \\
\text { apenas a consideração de } \\
\text { dados específicos correlatos. } \\
\text { Foi identificada a } \\
\text { intersetorialidade apenas na } \\
\text { execução do Projeto } \\
\text { Produtor de Água do Rio } \\
\text { Camboriúvi1, desenvolvido de } \\
\text { forma cooperada entre os } \\
\text { municípios. } \\
\end{array}$ \\
\hline \multirow[b]{2}{*}{3} & \multirow{2}{*}{ INTEGRALIDADE } & \multirow{2}{*}{$\begin{array}{l}\text { Considera os } \\
\text { critérios e } \\
\text { componentes } \\
\text { mínimos exigidos } \\
\text { em cada } \\
\text { temática }\end{array}$} & \multirow{2}{*}{$\begin{array}{l}\text { a) Abrange os elementos } \\
\text { mínimos plenamente }=3 ; \\
\text { b) Abrange os elementos } \\
\text { mínimos parcialmente }=2 ; \\
\text { c) Abrange parte dos } \\
\text { elementos mínimos }=1 ; \\
\text { d) Não identificado }=0\end{array}$} & Camboriú & 2 & $\begin{array}{l}\text { Os planos analisados } \\
\text { atendem ao escopo mínimo } \\
\text { exigido nas respectivas } \\
\text { legislações, porém de forma } \\
\text { parcial. }\end{array}$ \\
\hline & & & & $\begin{array}{l}\text { Balneário } \\
\text { Camboriú }\end{array}$ & 2 & $\begin{array}{c}\text { Os planos analisados } \\
\text { atendem ao escopo mínimo } \\
\text { exigido nas respectivas } \\
\text { legislações, porém de forma } \\
\text { parcial. }\end{array}$ \\
\hline \multirow[b]{2}{*}{4} & \multirow[b]{2}{*}{$\begin{array}{l}\text { PARTICIPAÇÃO } \\
\text { SOCIAL }\end{array}$} & \multirow{2}{*}{$\begin{array}{l}\text { Avalia o grau de } \\
\text { participação } \\
\text { social nas fases } \\
\text { de planejamento, } \\
\text { implementação e } \\
\text { avaliação das } \\
\text { políticas e planos } \\
\text { em cada } \\
\text { município. }\end{array}$} & \multirow{2}{*}{$\begin{array}{l}\text { a) Ampla participação social } \\
\text { com adoção de metodologia } \\
\text { participativa desde a fase de } \\
\text { elaboração dos planos até à } \\
\text { aprovação em Audiência } \\
\text { Pública; autonomia da } \\
\text { sociedade nos processos } \\
\text { decisórios; órgãos } \\
\text { colegiados ativos e } \\
\text { existência de mecanismos de } \\
\text { controle social = } 3 \\
\text { b) Participação dos atores } \\
\text { sociais em parte dos } \\
\text { processos, órgãos colegiados } \\
\text { ativos e Audiência Pública de } \\
\text { aprovação do plano = } 2 \\
\text { c) Baixo grau de } \\
\text { envolvimento dos atores } \\
\text { sociais, órgãos colegiados } \\
\text { inexistem ou estão inativos } \\
\text { Audiência pública de } \\
\text { aprovação = 1 } \\
\text { c) Não atende = o }\end{array}$} & Camboriú & 1 & $\begin{array}{l}\text { A participação social se dá de } \\
\text { forma muito insatisfatória e } \\
\text { há órgãos colegiados } \\
\text { inativos. }\end{array}$ \\
\hline & & & & $\begin{array}{l}\text { Balneário } \\
\text { Camboriú }\end{array}$ & 2 & $\begin{array}{l}\text { A participação social ocorre } \\
\text { em parte das etapas de } \\
\text { elaboração dos planos, } \\
\text { geralmente para cumprir os } \\
\text { aspectos mínimos exigidos. } \\
\text { Não se identificou processo } \\
\text { participativo e autonomia } \\
\text { social. }\end{array}$ \\
\hline 5 & $\begin{array}{l}\text { DIMENSÃO } \\
\text { TEMPORAL }\end{array}$ & $\begin{array}{l}\text { Avalia o } \\
\text { horizonte de } \\
\text { tempo } \\
\text { usualmente } \\
\text { aplicado no }\end{array}$ & $\begin{array}{l}\text { a) Maior parte dos planos e } \\
\text { ações considera o } \\
\text { planejamento de médio ou } \\
\text { longo prazo (10/20 anos ou } \\
\text { mais), prevê a revisão a cada }\end{array}$ & Camboriú & 2 & $\begin{array}{l}\text { Maior parte dos planos não } \\
\text { atende ao planejamento de } \\
\text { longo prazo ou está } \\
\text { desatualizado. }\end{array}$ \\
\hline
\end{tabular}

${ }^{11}$ O Projeto Produtor de Água do Rio Camboriú foi criado através da Lei Municipal n 3.026, de 26 de novembro de 2009. O objetivo é a recuperação ambiental da bacia considerando a relação água-solo-floresta, no intuito de proteção da cobertura vegetal e melhora da disponibilidade hídrica e da qualidade de água, por meio de pagamento por serviços ambientais aos produtores rurais que adotam práticas conservacionistas nas suas propriedades. 


\begin{tabular}{|c|c|c|c|c|c|c|}
\hline & & $\begin{array}{l}\text { planejamento } \\
\text { urbano e } \\
\text { ambiental dos } \\
\text { municípios em } \\
\text { análise. }\end{array}$ & $\begin{array}{l}4 \text { anos, possui metas } \\
\text { progressivas e plano } \\
\text { atualizado = } 3 \\
\text { b) Maior parte dos planos e } \\
\text { ações considera o } \\
\text { planejamento de médio ou } \\
\text { longo prazo ( } 10 / 20 \text { anos ou } \\
\text { mais); prevê a revisão a cada } \\
4 \text { anos, mas se encontra } \\
\text { desatualizado = } 2 \\
\text { c) Maior parte dos planos e } \\
\text { ações considera o } \\
\text { planejamento de curto } \\
\text { prazo, prevê a revisão, mas } \\
\text { se encontra desatualizado = } \\
1 \\
\text { c) Não identificado = o }\end{array}$ & $\begin{array}{l}\text { Balneário } \\
\text { Camboriú }\end{array}$ & 2 & $\begin{array}{l}\text { Maior parte dos planos está } \\
\text { desatualizado, inclusive o } \\
\text { Plano Diretor que foi } \\
\text { elaborado em } 2006 \text { e está } \\
\text { pendente de atualização. }\end{array}$ \\
\hline \multirow[b]{2}{*}{6} & \multirow[b]{2}{*}{$\begin{array}{c}\text { DIMENSÃO } \\
\text { DEMOGRÁFICA }\end{array}$} & \multirow[b]{2}{*}{$\begin{array}{l}\text { O planejamento } \\
\text { é coerente } \\
\text { quanto aos } \\
\text { aspectos } \\
\text { populacionais? }\end{array}$} & \multirow{2}{*}{$\begin{array}{l}\text { a) A dimensão demográfica } \\
\text { será pontuada em até } 1 \\
\text { ponto para cada atributo } \\
\text { atendido, podendo haver } \\
\text { somatória até } 5: \\
\text { - População fixa; } \\
\text { - População flutuante; } \\
\text { - Projeção demográfica de } \\
\text { longo prazo; } \\
\text { - Migração, incluindo } \\
\text { aspectos migratórios } \\
\text { pendulares; } \\
\text { b) Não identificado =0 } \\
\end{array}$} & Camboriú & 1 & $\begin{array}{l}\text { Os planos são falhos, maior } \\
\text { parte não considera mais de } 1 \\
\text { dos aspectos demográficos. }\end{array}$ \\
\hline & & & & $\begin{array}{l}\text { Balneário } \\
\text { Camboriú }\end{array}$ & 2 & $\begin{array}{l}\text { Maior parte dos planos } \\
\text { considera a população fixa e } \\
\text { flutuante, porém a projeção } \\
\text { demográfica, para fins de } \\
\text { planejamento de ações, não } \\
\text { é considerada } \\
\text { adequadamente, da mesma } \\
\text { forma para os aspectos } \\
\text { migratórios. }\end{array}$ \\
\hline \multirow[b]{2}{*}{7} & \multirow[b]{2}{*}{$\begin{array}{l}\text { PRESENÇA DE } \\
\text { INSTRUMENTOS DE } \\
\text { PLANEJAMENTO } \\
\text { URBANÍSTICO E } \\
\text { AMBIENTAL }\end{array}$} & \multirow[b]{2}{*}{\begin{tabular}{l|} 
São considerados \\
instrumentos de \\
planejamento \\
municipal \\
relativos à \\
temática do \\
trabalho àqueles \\
previstos na \\
Política Nacional \\
de Meio \\
Ambiente e no \\
Estatuto das \\
Cidades.
\end{tabular}} & \multirow{2}{*}{$\begin{array}{l}\text { a) Aplicar até 1 ponto para } \\
\text { cada item plenamente } \\
\text { atendido, sendo que a } \\
\text { pontuação máxima será } 5 \text {. A } \\
\text { questão orientativa consiste } \\
\text { em identificar instrumentos } \\
\text { que visam inibir a } \\
\text { degradação ambiental ou } \\
\text { instrumentos que incentivam } \\
\text { à proteção do meio } \\
\text { ambiente: } \\
\text { - Instrumentos de regulação } \\
\text { do ordenamento territorial } \\
\text { em prol da proteção } \\
\text { ambiental, como exemplo o } \\
\text { zoneamento ecológico } \\
\text { econômico } \\
\text { - Instrumentos de } \\
\text { fiscalização e sanção; } \\
\text { - Instrumentos de tomada de } \\
\text { decisão como Avaliação de } \\
\text { Impacto Ambiental EIV e EIA } \\
\text { - Instrumentos econômicos } \\
\text { de incentivo tributário ou } \\
\text { financeiro; } \\
\text { b) Não identificado }\end{array}$} & Camboriú & 1 & $\begin{array}{l}\text { Não se identificou } \\
\text { instrumentos de uso e } \\
\text { ocupação do solo e } \\
\text { instrumentos econômicos em } \\
\text { prol da proteção ambiental. } \\
\text { Não há zoneamento } \\
\text { ecológico econômico. }\end{array}$ \\
\hline & & & & $\begin{array}{l}\text { Balneário } \\
\text { Camboriú }\end{array}$ & 2 & $\begin{array}{l}\text { Há presença dos } \\
\text { instrumentos citados, porém } \\
\text { visando incentivar a } \\
\text { ocupação e aumento dos } \\
\text { índices construtivos sem } \\
\text { preocupação em regular a } \\
\text { ocupação com preocupação } \\
\text { ambiental. Não há } \\
\text { zoneamento ecológico } \\
\text { econômico. Identificou-se } \\
\text { uso de EIV EIA, instrumentos } \\
\text { de fiscalização/sanção } \\
\text { significativos no setor do } \\
\text { saneamento básico. }\end{array}$ \\
\hline \multirow[b]{2}{*}{8} & \multirow{2}{*}{$\begin{array}{l}\text { MECANISMOS DE } \\
\text { MONITORAMENTOE } \\
\text { AVALIAÇÃO }\end{array}$} & \multirow{2}{*}{$\begin{array}{l}\text { Prevê } \\
\text { mecanismos de } \\
\text { controle, } \\
\text { monitoramento e } \\
\text { avaliação tais } \\
\text { como conselhos } \\
\text { relatórios; metas } \\
\text { e indicadores }\end{array}$} & \multirow{2}{*}{$\begin{array}{l}\text { a) Aplicar até } 1 \text { ponto para } \\
\text { cada item atendido, sendo } \\
\text { que a pontuação máxima } \\
\text { será } 5 . \\
\text { - Conselho ativo; } \\
\text { - Metas definidas; } \\
\text { - Prevê indicadores para } \\
\text { nortear o monitoramento } \\
\text { das ações; } \\
\text { - Prevê relatórios de gestão; } \\
\text { - Avaliação sistemática e } \\
\text { revisão dos planos } \\
\text { b) Não identificado = o }\end{array}$} & Camboriú & 1 & $\begin{array}{l}\text { Parte dos planos analisados } \\
\text { atende ao item Conselho } \\
\text { Ativo e parte prevê metas } \\
\text { definidas, razão pela qual se } \\
\text { deu a nota } 1 . \text { O critério mais } \\
\text { precário é a falta de previsão } \\
\text { de mecanismos de avaliação. }\end{array}$ \\
\hline & & & & $\begin{array}{l}\text { Balneário } \\
\text { Camboriú }\end{array}$ & 2 & $\begin{array}{l}\text { Parte dos planos analisados } \\
\text { possui conselhos ativos, } \\
\text { parte possui metas definidas. } \\
\text { Há previsão de indicadores. } \\
\text { Não há previsão de relatórios } \\
\text { de gestão e apenas } \\
\text { considera-as a necessidade }\end{array}$ \\
\hline
\end{tabular}




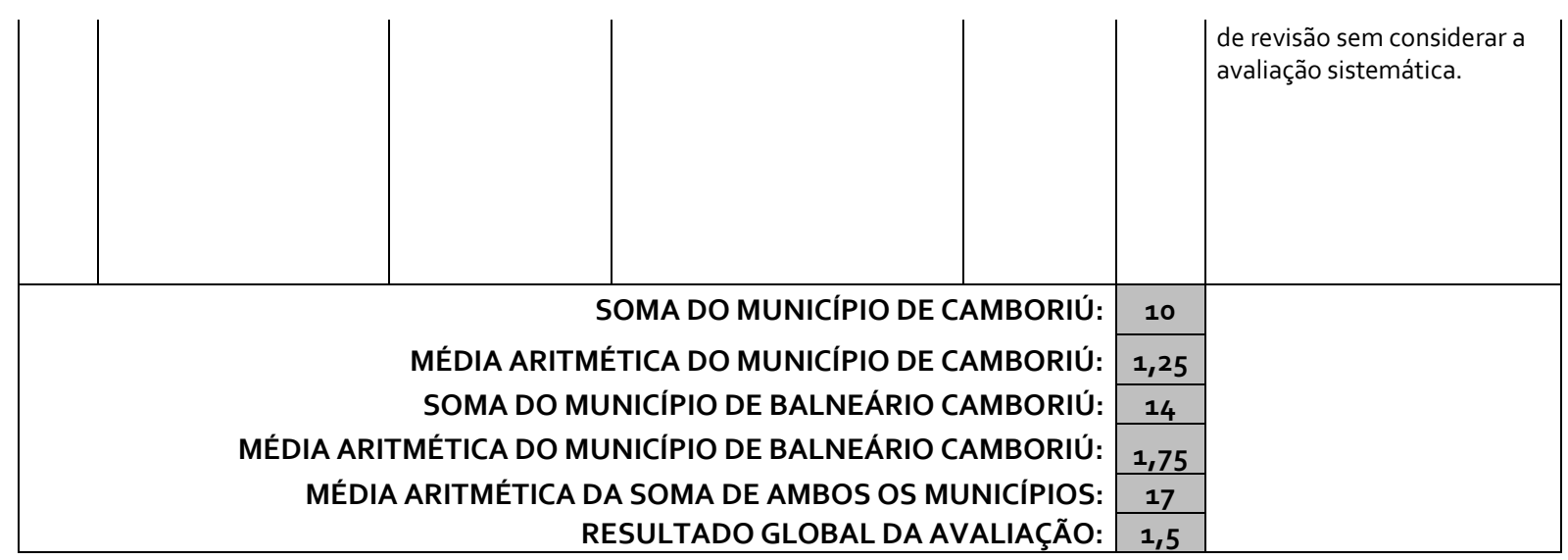

(i) média menor ou igual a 5 e maior que 3: MUITO SATISFATÓRIO

(ii) média menor ou igual a 3 e maior que 2: SATISFATÓRIO

(iii) média menor ou igual a 2 e maior que 1 : INSATISFATÓRIO (iiii) média menor ou igual a 1: MUITO INSATISFATÓRIO
O planejamento urbanístico e ambiental no âmbito da bacia hidrográfica do Rio Camboriú e Contíguas apresenta-se INSATISFATÓRIO.

Fonte: elaborado pelos autores.

Indicadores

Outro aspecto que complementa a análise do objeto investigado são os indicadores. Há uma infinidade de indicadores ou índices que refletem as condições de desenvolvimento e sustentabilidade dos municípios.

Meirinho, Bucior e Dias (2016) defendem a importância do equilíbrio das dimensões econômica, social e ambiental, relacionando diferentes indicadores como, por exemplo, o Produto Interno Bruto - PIB, o Índice de Desenvolvimento Humano - IDH, EPI Enviromental Performance Index. Destacam referências que buscam aplicações práticas nos municípios como os índices do Programa Cidades Sustentáveis, bem como analisam as dimensões dos 55 indicadores de Desenvolvimento Sustentável do IBGE. Dentre elas, na área ambiental, são citados os indicadores de concentração de polventes no ar em áreas urbanas, queimadas e incêndios florestais e balneabilidade dos oceanos.

Independentemente da base de indicadores utilizada, acredita-se na importância de considerar as diferentes dimensões, para que se possa ter parâmetros de análise condizentes à busca do desenvolvimento sustentável nos municípios.

Neste sentido, a pesquisa considerou os dados de ambos os municípios a partir do Sistema de Indicadores de Desenvolvimento Municipal Sustentável da Federação Catarinense dos Municípios FECAM, que visa fortalecer os processos de planejamento, avaliação e tomadas de decisão. Ver Tabela 4. 
Tabela 4 - Aspectos integrados - Índice de Desenvolvimento Municipal Sustentável

\begin{tabular}{|c|c|c|}
\hline \multicolumn{2}{|c|}{ Índice de Desenvolvimento Municipal Sustentável } \\
\hline Índice/ Dimensão & $\begin{array}{c}\text { Balneário } \\
\text { Camboriú }\end{array}$ & Camboriú \\
\hline IDMS & 0,661 & 0,629 \\
\hline Sócio cultural & 0,777 & 0,644 \\
\hline Econômica & 0,619 & 0,438 \\
\hline Ambiental & 0,612 & 0,876 \\
\hline Político Institucional & 0,635 & 0,559 \\
\hline
\end{tabular}

Fonte: FECAM, 2019.

\section{Resultados}

O Gráfico 1 evidencia o número de planos, fundos e conselhos instituídos em cada município.

No município de Balneário Camboriú, dos nove planos considerados relevantes, existem apenas cinco, sendo que as Tabelas 1 e 2 indicam que 4 deles estão desatualizados, necessitando de revisão. Existem seis fundos e seis conselhos instituídos. As áreas não atendidas por plano municipal são: defesa civil, meio ambiente, mudanças climáticas e drenagem pluvial.

Quanto ao município de Camboriú, do total de nove planos considerados na pesquisa, cinco foram instituídos, sendo que as Tabelas 1 e 2 indicam que três estão atualizados e dois necessitam de revisão. Existem três fundos e três conselhos. Assim, temos seis áreas desprovidas de plano, são elas: mudanças climáticas; defesa civil, habitação de interesse social e drenagem pluvial. 
Gráfico 1 - Número de instrumentos de planejamento existentes em cada município

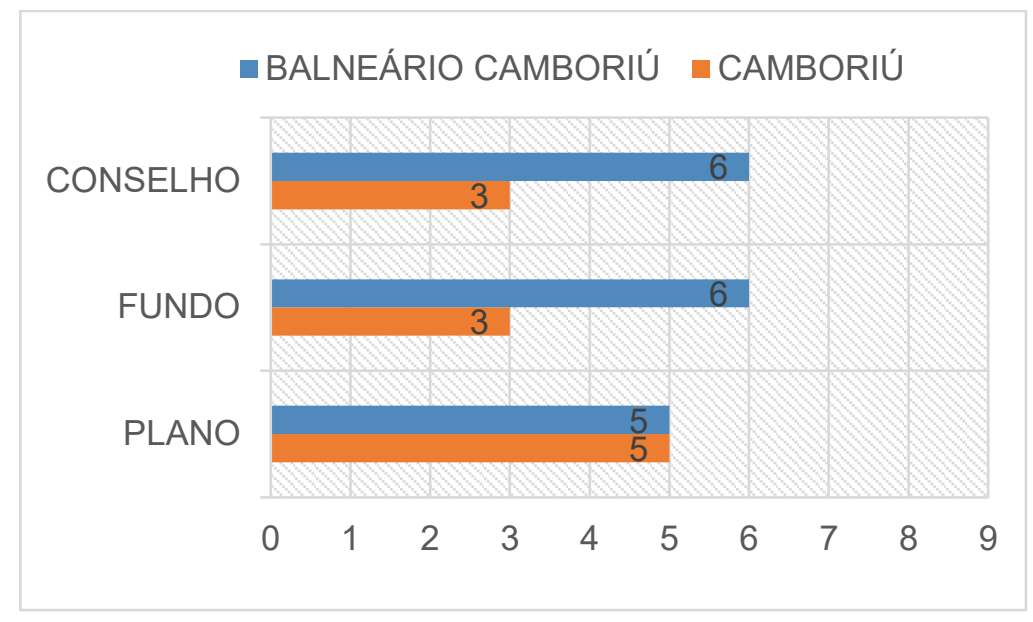

Fonte: elaborado pelos autores.

O gráfico 2 apresenta a pontuação alcançada pelos municípios em cada um dos critérios analisados. Em nenhum dos critérios os municípios atingiram pontuação superior a dois.

No que se refere à intersetorialidade e a compatibilidade dos planos e políticas, os municípios tiveram um desempenho ainda inferior, não ultrapassando 1 ponto. Isto significa que o planejamento não considera a intersetorialidade, não há planejamento alinhado entre os setores do mesmo município, tampouco entre os municípios.

Gráfico 2 - Resultado da Matriz de Avaliação

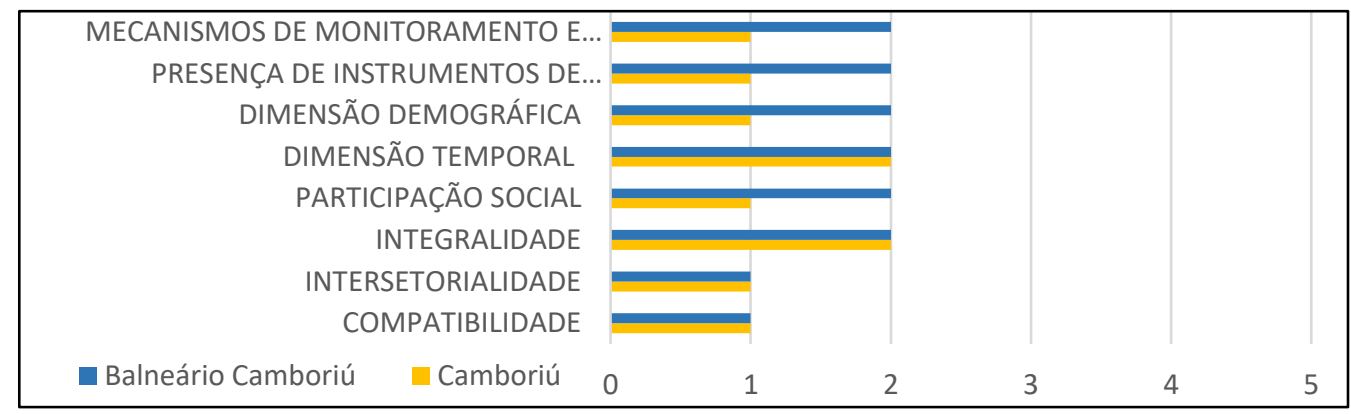

Fonte: elaborado pelos autores.

O Gráfico 3 apresenta a média aritmética do município de Camboriú, que alcançou 1,25 pontos, e a média aritmética de Balneário Camboriú, que atingiu 1,75 pontos. A média final de ambos os municípios totalizou 1,5. 
Gráfico 3-Média de pontuação dos municípios

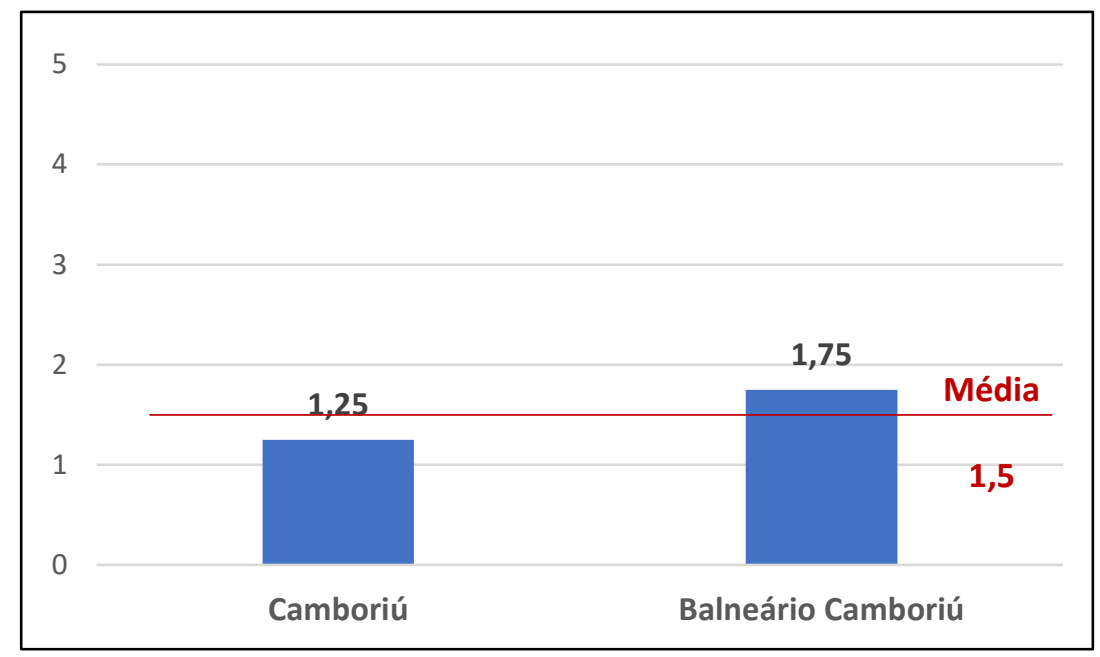

Fonte: elaborado pelos autores.

Sendo assim, o conceito final apresentado, como na avaliação apresentada na Tabela 3, resultou em um planejamento urbanístico e ambiental insatisfatório.

\section{Considerações finais}

Os planos municipais não atendem ao mínimo exigido nas legislações urbanísticas. Devido ao baixo grau de participação da sociedade e à ausência de instrumentos de monitoramento e avaliação, a execução dos planos, a gestão e o controle social também ficam comprometidos.

Os processos de planejamento não observam, de forma adequada, os princípios democráticos de participação da sociedade. Há falhas na organização de espaços e órgãos colegiados e na utilização de metodologias adequadas para a efetiva participação dos cidadãos. O planejamento mais adotado é do tipo sistêmico, não havendo autonomia nos processos por parte da sociedade.

A ausência de relação entre os diferentes setores e o fato de não haver planejamento integrado demonstram a dificuldade de se alcançar a solução para problemas comuns entre os municípios, como a degradação ambiental, a falta de disponibilidade hídrica para atender às demandas de abastecimento público, a polvição dos rios e praias, as enchentes, as inundações e os problemas de mobilidade urbana. 
Ficou demonstrado que o crescimento populacional ocorreu exponencialmente em ambos os municípios, devido ao desenvolvimento turístico e estímulo do mercado imobiliário. Devido à ausência de um planejamento ambiental integrado, as desigualdades sociais, econômicas e ambientais estão refletidas nos índices analisados. Um município desenvolveu-se mais do que o outro. O rio nasce num município e deságua no outro. $\mathrm{A}$ polvição não respeita limites territoriais. Os corpos hídricos fazem parte do mesmo sistema de drenagem. Os impactos ambientais abrangem a bacia como um todo. Há necessidade de maior integração nas políticas públicas ambientais e os planos setoriais de ambos os municípios.

Atualmente, em que pese a autonomia dos municípios, há que se repensar a importância do planejamento integrado entre os dois municípios que compartilham a bacia ou na escala de região metropolitana. Projetos que ocorrem de forma cooperada entre os municípios, como o Produtor de Água do Rio Camboriú, devem ser estimulados. Ambos os municípios dependem da proteção de áreas estratégicas para a disponibilidade hídrica e para a contenção de cheias. Estes problemas indicam a necessidade de um planejamento conjunto, não somente razão de escala de planejamento de bacia para fins de proteção dos recursos naturais, mas, também, em razão da interdependência entre os municípios.

\section{Referências}

BALNEÁRIO CAMBORIÚ. Lei Municipal n².686, de 19 de dezembro de 2006. Dispõe sobre a revisão do Plano Diretor do Município de Balneário Camboriú. Disponível em: http://leismunicipa.is/kcbal. Acesso em: 10 de dez. 2019.

BALNEÁRIO CAMBORIÚ. Lei Municipal n. 2.794 de janeiro de 2008. Disciplina o uso e a ocupação do solo, as atividades urbanização e dispõe sobre o parcelamento do solo no território do município de Balneário Camboriú. Disponível em: http://leismunicipa.is/acbdl. Acesso em: 10 de dez. 2019.

\section{BALNEÁRIO CAMBORIÚ. Lei Municipal n. 3.026, de 26 de novembro de 2009. Cria o} Projeto Produtor de Água, autoriza a Empresa Municipal de Água e Saneamento - EMASA a prestar apoio financeiro aos proprietários rurais e dá outras providências. Disponível em: http://leismunicipa.is/cabem. Acesso em: 10 de dez. 2019.

BALNEÁRIO CAMBORIÚ. Lei Municipal n 4.259, de 22 de abril de 2019. Reconhece o Marco de Fundação de Balneário Camboriú, padroniza a legislação municipal com "Fecho de Lei" e dá outras providências. Disponível em: http://leismunicipa.is/qmnxk. Acesso em: 10 de dez. 2019. 
CORRÊA, Isaque de Borba. História de Duas Cidades: Camboriú e Balneário Camboriú. 2. ed. (ampliada). Balneário Camboriú: Ed. do Autor, 2019.

DACOL, Kelli Cristina. O desenvolvimento do sistema de esgotamento sanitário em Balneário Camboriú - SC à luz das políticas públicas. Dissertação (Mestrado) - Programa de Pós Graduação em Planejamento Territorial e Desenvolvimento Socioambiental, Universidade do Estado de Santa Catarina, Florianópolis, 2013. 102 p.

CIRAM/EPAGRI - Centro de Informações de Recursos Ambientais e de Hidrometeorologia/Empresa de Pesquisa Agropecuária e Extensão Rural de Santa Catarina. Inventário de Terras na Bacia do Rio Camboriú. Florianópolis, 2010. Disponível em: http://www.ciram.epagri.sc.gov.br/index.php?option=com content\&view=article\&id $=559 \& \mathrm{I}$ temid=200. Acesso em: 15 de dez de 2019.

FECAM - Federação Catarinense de Municípios. Sistema de Indicadores de Desenvolvimento Municipal Sustentável. FECAM, 2019 Disponível em: https://indicadores.fecam.org.br/index/index/ano/2019. Acesso em: 15 de dez. 2019.

IBGE - Instituto Brasileiro de Geografia e Estatística, 2019. Disponível em: https://www.ibge.gov.br/cidades-e-estados.html. Acesso em: 11 de dez. 2019.

IPEA - Instituto de Pesquisa Econômica Aplicada. Brasil em Desenvolvimento: Estado, Planejamento e Políticas Públicas - Sumário Analítico. José Celso Cardoso Jr. (Coord). Brasília, 2010.

LEME, Paulo. O Semeador. Vida e Obra de Um Vencedor. Balneário Camboriú: Ed. Taqui, 2010, p.69.

MEIRINHO, André Furlan; BUCIOR, Elvis Roni; DIAS, Vera Lúcia Nehls. Gestão Pública para Resultados e Indicadores de Desenvolvimento Sustentável. Para Onde? UFRGS, v.8, p. 114$122,2016$.

SCHLIKMANN, Mariana. Do Arraial de Bonsucesso a Balneário Camboriú: mais de cinquenta anos de história. Balneário Camboriú: Fundação Cultural de Balneário Camboriú, 2016. $82 \mathrm{p}$.

SKALEE, Milena; REIS, Alma Francisco. Crescimento urbano-turístico: traçado e permanências urbanas em Balneário Camboriú. Scripta Nova Revista Electrônica de Geografia y Ciências Sociales. Barcelona: Universidad de Barcelona, vol. XII, n. 270 (88), 1 de ago. de 2008. Mestrado em Geografia. Disponível em: http://www.ub.edu/geocrit/sn/sn270/sn-270-88.htm. Acesso em: 15 de dez. 2019.

SANTA CATARINA. Comitê da Bacia Hidrográfica do Rio Camboriú e Contíguas. Plano de Recursos Hídricos da Bacia Hidrográfica do Rio Camboriú e Contíguas, Secretaria de Desenvolvimento Econômico e Sustentável do Estado de Santa Catarina: 2018. 
SANTA CATARINA. Lei n⿳0 5.630, de 20 de novembro de 1979. Altera toponímia.

Disponível em: http://www.leisestaduais.com.br/sc/lei-ordinaria-n-5630-1979-santacatarina-altera-toponimia. Acesso em: 10 de dez. 2019.

SANTA CATARINA. Relatório Técnico do Plano Estadual de Gerenciamento Costeiro: condicionantes para desenvolvimento urbano dos municípios de Balneário Camboriú e Camboriú. Secretaria do Estado de Planejamento: 2015.

SOUZA, Marcelo Lopes. Mudar a Cidade: uma introdução crítica ao planejamento e à gestão urbanos. 6. ed. Rio de Janeiro: Bertrand Brasil, 2010.

URBAN, Sandro Rogério. Uso do solo na bacia hidrográfica do Rio Camboriú (SC) e sua influência sobre a qualidade da água. Itajaí: UNIVALI, 2008. 112 p. Dissertação (Mestrado) - Programa de Pós-Graduação em Ciência e Tecnologia Ambiental, Universidade do Vale do Itajaí, Itajaí, 2008.

\section{Detalhes dos autores}

André Furlan Meirinho

Bacharel em Administração com Habilitação em Marketing, Mestre e Doutorando no Programa de Planejamento Territorial e Desenvolvimento Socioambiental Universidade do Estado de Santa Catarina UDESC. E-mail: afmeirinho@yahoo.com.br.

Kelli Cristina Dacol

Bacharel em Administração Pública, Mestre e Doutoranda no Programa de Planejamento Territorial e Desenvolvimento Socioambiental, Universidade do Estado de Santa Catarina - UDESC. E-mail: kellidacol@gmail.com.

Valério Alécio Turnes

Engenheiro Agrônomo, Mestre em Engenharia Civil, Doutor em Engenharia da Produção pela Universidade do Estado de Santa Catarina - UFSC. E-mail: valerio.turnes@yahoo.com.br. 